\title{
Bioleaching of cobalt and zinc from pyrite ore in relation to calcitic gangue content
}

\author{
F. Baldi, A. Bralia, F. Riccobono and G. Sabatini
}

\begin{abstract}
Bloleaching of a pyrite ore containing high concentrations of cobalt $(0.1 \%)$ and zinc $(0.065 \%)$ was affected by small amounts of calcitic gangue (from 0.01 to $1.01 \%$ ). Results from an air-lift percolator and from Erlenmeyer flask experiments show that a small percentage of calcite ralses the $\mathrm{pH}$ and arrests the growth of the acidophilic bacterlum Thlobaclllus ferrooxidans. In percolator experiments, when calcite is completely removed by the continuous addition of small quantities of acid, and the pH of the llquor becomes acld, the micro-organism begins to grow and to bio-oxidize the pyrite ore. The growth of $T$. ferrooxidans shows different lag phase spans (Irom 13 to 190 days) depending on carbonate dissolution. The metals Fe, Zn and $C_{0}$ are released into the leaching solution together at different rates after a lag-time which depends on calcite concentrations in pyrile gangue. Metal ratlos in the mineral bulk are different from those in the liquor, Zn dissolving 5 times more readily than Co. Bloleaching rates for metal removal from pyrite are higher in percolator (for Fe, from 5 to $15 \mathrm{mg} / \mathrm{l} / \mathrm{h}$ ) than in flask experiments (from 0.5 to $2 \mathrm{mg} / \mathrm{l} / \mathrm{h}$ ), but the lag phases are shorter (irom 2 to 65 days). The differences between the two systems are related to calcite dissolution and gypsum preclpitation.
\end{abstract}

(C) 1991 Rapid Communications of Oxford Ltd
The continuing world-wide depletion of metal ore deposits and the accumulation of tailings, which cannot be further processed by conventional means, is encouraging the development of bioleaching technology (bio-hydrometallurgy) for recovering metals such as copper and uranium (Brierley 1978; Kelly et al. 1979) and also 'strategic' metals such as gold, silver and cobalt (Ehrlich 1987; Pinches et al. 1987; Wichlacz \& Thompson 1987).

The bioleaching of sulphide ores may be performed by means of the acidophilic and chemolithotrophic bacterium Thiobacillus ferrooxidans or co-cultures of this micro-organism with other thiobacilli or acidophilic bacteria (Dugan et al. 1970; Groudev et al. 1978; Schafer 1983). However, this biotechnological process is not always successful. High concentrations of toxic metals $(\mathrm{Hg}, \mathrm{As}, \mathrm{Sb}$, etc.) in the sulphide ore lattice inhibit bacterial catalysis (Imai et al. 1975; Barbic 1977; Ingledew 1982; Mahapatra \& Mishra 1984; Paknikar \& Agate 1987) as these metals are released in the leaching solution. Metal-resistant strains of T. ferrooxidans can cope with unfavourable conditions of this kind (Tuovinen \& Kelly 1974; Sugio et al. 1981; Baldi \& Olson 1987), and grow well in the presence of high concentrations of these toxic cations. The metabolic activity of acidophilic $T$. ferrooxidans can also be influenced by carbonate compounds (Ishikawa et al. 1983; Khalid et al. 1987). It is obvious that carbonates buffer the acidic bioleaching solution and inactivate acidophilic bacteria (Wallace et al. 1976; Boseker et al. 1978). However, it is of industrial interest to investigate the concentrations of carbonates that affect the bioleaching process, since base metal ore deposits often contain carbonate gangue.

In industrial situations, in which tonnes of mineral ores are bioprocessed, a small percentage of carbonates might cause the failure or delay of bioleaching. Consequently, the carbonate content of ores might be an economic limiting factor in an industrial bioleaching plant.

Sulphide ores from different mines in Italy: Funtana Raminosa, Monteneve and Campiano, contain valuable metals including $\mathrm{Zn}, \mathrm{Cu}$ and $\mathrm{Co}$ which may possibly be recovered by biological methods. Preliminary bioleaching experiments with these ores were conducted in our laboratory for several months. The sulphides were inoculated with different strains of $T$. ferrooxidans isolated from the respective 
F. Baldi is with the Università di Siena, Dipartimento di Biologia Ambientale, via P. A. Mattioli, 4, 1-53100 Siena. A. Bralia, F. Riccobono and $G$. Sabatini are with the Universita di Siena, Istituto di Mineralogia $1-53100$ Siena, Italy. F. Baldi is the corresponding author.

Table 1. Composition of pyrite from Campiano mine.

\begin{tabular}{lc} 
Components & \\
$\mathrm{FeS}_{2}{ }^{*}$ & $98.1 \%$ \\
$\mathrm{CaCO}_{3}{ }^{*}$ & $1.01 \%$ \\
$\mathrm{Ca} \dagger$ & $0.40 \%$ \\
$\mathrm{Co} \dagger$ & $0.10 \%$ \\
$\mathrm{Mn} \dagger$ & $215 \mathrm{mg} / \mathrm{kg}$ \\
$\mathrm{Zn} \dagger$ & $650 \mathrm{mg} / \mathrm{kg}$ \\
$\mathrm{Pb} \dagger$ & $205 \mathrm{mg} / \mathrm{kg}$ \\
$\mathrm{Cu} \dagger$ & $25 \mathrm{mg} / \mathrm{kg}$ \\
$\mathrm{Ag} \dagger$ & $5 \mathrm{mg} / \mathrm{kg}$ \\
$\mathrm{Ni \dagger}$ & $<10 \mathrm{mg} / \mathrm{kg}$ \\
$\mathrm{Cd} \dagger$ & $<0.1 \mathrm{mg} / \mathrm{kg}$ \\
\hline
\end{tabular}

* Determined by X-ray diffractometry. $\uparrow$ Determined by flame atomic absorption spectrophotometry. mines. No bioleaching activity was detected, evidently because carbonates (from 1 to $10 \%$ ) prevent the biological oxidation of the mineral ores.

The aim of the present research is: (1) to determine the potential recovery of Co and $\mathrm{Zn}$ from pyrites of the Campiano mine; (2) to determine the effect of carbonates on the bio-extraction of $\mathrm{Co}$ and $\mathrm{Zn}$, with particular reference to carbonate gangue and (3) to investigate how long $T$. ferrooxidans can survive at neutral $\mathrm{pH}$.

\section{Materials and Methods}

Pyrite

The pyrite from the Campiano mine (southern Tuscany) was chosen because of its high $\mathrm{Co}$ and $\mathrm{Zn}$ content. Twenty kilograms of pyrite was ground to obtain $500 \mathrm{~g}$ of 250 to $500 \mu \mathrm{m}$ grain size containing $1.01 \%$ of total carbonates. The sample was split into two subsamples: one was treated with $20 \%(\mathrm{v} / \mathrm{v})$ acetic acid solution to remove carbonates $(0.01 \%$ carbonate residues). The purity of pyrite and type of carbonate gangue was determined by X-ray diffractometry (Siemens D500) using internal standards. The megacrystal from the Campiano mine was $98.1 \%$ pyrite, the remainder being $1.01 \% \mathrm{CaCO}_{3}$ as calcite, $0.1 \% \mathrm{Co}, 0.065 \% \mathrm{Zn}$, and other trace metals (Table 1).

\section{Metal Analysis}

Metal concentrations of $\mathrm{Fe}, \mathrm{Zn}, \mathrm{Cu}, \mathrm{Ca}$ and uthers (Table 1) were determined by holding $0.5 \mathrm{~g}$ of sample treated with $50 \mathrm{ml} 6 \mathrm{M} \mathrm{HCl}$ both as original pyrite and as carbonate-free pyritc, at $90^{\circ} \mathrm{C}$ ovcrnight. The sample was cooled to room temperature and made up to $100 \mathrm{ml}$. Metals were determined by flame atomic absorption spectrophotometry (AAS, Perkin Elmer model 5000). The standard deviation was $5.1 \%$ for $\mathrm{Fe}$, $6.3 \%$ for $\mathrm{Ca}, 6.1 \%$ for $\mathrm{Zn}$ and $7.5 \%$ for Co. Metal analysis in the leaching solution of percolators and Erlenmeyer flasks was carried out by flame AAS after adding $2 \mathrm{ml}$ conc. $\mathrm{HNO}_{3}$ and $7 \mathrm{ml}$ of double distilled water to $1 \mathrm{ml}$ of sample.

\section{Organism and Culture Conditions}

T. ferrooxidans strain 13661 was kindly supplied by G.J. Olson and grown in $9 \mathrm{~K}$ medium (Silverman \& Lundgren 1959). The bacteria were cultivated routinely in $50 \mathrm{ml}$ of $9 \mathrm{~K}$ medium in $250 \mathrm{ml}$ Erlenmeyer flasks and agitated at $150 \mathrm{rev} / \mathrm{min}$ at $30^{\circ} \mathrm{C}$ or in 2.0 litres of $9 \mathrm{~K}$ medium in a 2.5 litre Erlenmeyer flask equipped with a sterile glass tube plugged with glass wool, through which compressed air was passed to vigorously aerate the inoculated medium. When all $\mathrm{FeSO}_{4}$ was oxidized, 2.0 litres of culture was harvested by centrifuging at $3600 \times g$ for $20 \mathrm{~min}$. The cells were washed twice with $5 \mathrm{mM} \mathrm{H}_{2} \mathrm{SO}_{4}$, and then inoculated into air-lift percolators or the Erlenmeyer flasks.

\section{Standards}

T. ferrooxidans ATCC 13661 used here is the same as that used in an interlaboratory bioleaching study (Bioleaching working group, in preparation) of a reference pyrite (NIST-8455; National Institute of Standards \& Technology Gaithersburg, MD, USA). The average bioleaching rate of the reference pyrite using this strain, according to eight international laboratories, was $12.4 \mathrm{mg} / \mathrm{l} / \mathrm{h}$. The average value of our laboratory for three replicates was $7.8 \mathrm{mg} / \mathrm{l} / \mathrm{h} \pm 1.1$ (standard deviation).

\section{Microbial Protein Analysis}

The cell density in solution was determined by measuring protein content with a protein assay kit (BioRad). Bovine serum albumin (Sigma) solution was used as standard. Pyrite oxidation by cells was determined by measuring soluble iron. 
Air-lift Percolator Experiments

Air-lift percolators, as described elsewhere (Baldi \& Olson 1987), were used in the bioleaching experiments. Carbonate-free pyrite $(20 \mathrm{~g})$, original pyrite $(1.01 \%)$ and mixed samples with intermediate carbonate content $(0.25,0.50$ and $0.75 \%)$ were placed in percolators and immersed in $25 \mathrm{ml}$ of $9 \mathrm{~K}$ medium (minus $\mathrm{FeSO}_{4}$ ). Pulp density was $80 \%$. All five percolators were inoculated with $0.25 \mathrm{ml}$ of a suspension of a $T$. ferrooxidans culture containing $3.7 \mathrm{mg}$ protein $/ \mathrm{ml}$. Two percolators with sterile pyrite were not inoculated for use as controls. All percolators were continuously aerated, with humidified sterile air from an air-compressor, for one year at room temperature. The liquor (bioleaching solution) was sampled periodically (at intervals of 3 to 10 days) and analysed for $\mathrm{Ca}, \mathrm{Co}, \mathrm{Fe}, \mathrm{Zn}$ and $\mathrm{pH}$. At the outset, other metals were also measured: $\mathrm{Ag}, \mathrm{Cd}, \mathrm{Cu}, \mathrm{Mn}, \mathrm{Ni}$ and $\mathrm{Pb}$. Losses from the removal of sample aliquots ( $4 \%$ of total volume) and evaporation were 20 to $25 \%$ per week. The volume of the liquid in the percolators was maintained by refilling with $5 \mathrm{mM} \mathrm{H}_{2} \mathrm{SO}_{4}$. This led to the progressive dissolution of carbonates.

\section{Colloid Phase}

The colloid phase was analysed by draining all the liquid from the percolators at the end of the experiment. The liquor was centrifuged at $3600 \times \mathrm{g}$ for $30 \mathrm{~min}$ to remove cells and inorganic particlcs. The supcrnatant was spun at $242,500 \times g$ for $4 \mathrm{~h}$ with an ultracentrifuge. An aliquot of the residue was analysed for metal content and another aliquot was analysed by $\mathrm{X}$-ray diffractometry.

\section{Salt Precipitate in Percolators}

When the experiments had been underway for several weeks, a white precipitate was observed on the glass walls of percolators at the air-liquid interface. This compound was dried and analysed by $\mathrm{X}$-ray diffractometry.

\section{Erlenmeyer Flask Experiments}

The bioleaching experiments were repeated in Erlenmeyer flasks $(125 \mathrm{ml})$ for a period of 3 months at the optimal temperature $\left(30^{\circ} \mathrm{C}\right)$ (Kelly \& Harrison 1989).

Pyrite $\left(3 \mathrm{~g}\right.$ ) was immersed in $30 \mathrm{ml}$ of $9 \mathrm{~K}$ medium (minus $\mathrm{FeSO}_{4}$ ), with a pulp density of $10 \%(\mathrm{w} / \mathrm{v})$. The carbonate content of the pyrite samples was: $0.01,0.05$, $0.10,0.20,0.30,0.40,0.60$, and $1.01 \%$ (original pyrite). The intermediate carbonate contents were obtained by mixing the original pyrite with different quantities of carbonate-free pyrite. The pyrite samples were inoculated with $0.3 \mathrm{ml}$ of a dense T. ferrooxidans culture containing $4.4 \mathrm{mg}$ protein $/ \mathrm{ml}$. Two uninoculated samples were used as experiment controls. One ml of solution was collected each week and centrifuged at $12,000 \times \boldsymbol{g}$ to remove particles. Then the supernatant was analysed for metals as described above. In this case evaporation losses were negligible, but sampling took $3.3 \%$ of the total volume. The initial addition of $30 \mathrm{ml}$ of $9 \mathrm{~K}$ medium to $3 \mathrm{~g}$ of pyrite was sufficient to dissolve up to $0.30 \%$ of the carbonates.

\section{Acidity}

The titratable acidity in flask experiments was determined by titrating the sample with $0.01 \mathrm{M} \mathrm{NaOH}$ solution in the presence of phenophthalein (Skoog \& West 1979).

\section{Results}

\section{Percolator Experiments}

The continuous additions of acid to the percolators was not sufficient to completely dissolve the carbonate residue except in the pyrite sample with $0.01 \%$ of calcite 
Figure 1. Effect of $\mathrm{pH}(\mathrm{O})$ on $\mathrm{Fe}(\mathrm{O})$ solubilization by $T$. ferrooxidans from a pyrite ore containing $0.25 \%$ of calcitic gangue after 3 months of incubation in air-lift percolators.
Table 2. Bioleaching rates $(\mathrm{mg} / / \mathrm{h})$ for metals at different concentrations of calcite gangue in the percolator study.

\begin{tabular}{lllll}
\hline Metals & \multicolumn{4}{c}{ Calcite in pyrite ore } \\
\cline { 2 - 5 } & $\mathbf{0 . 0 1 \%}$ & $\mathbf{0 . 2 5} \%$ & $\mathbf{0 . 5 0} \%$ & $\mathbf{1 . 0 1} \%$ \\
$\mathrm{Fe}$ & 5.1 & 5.05 & 14.7 & 0 \\
$\mathrm{Zn}$ & 0.038 & 0.045 & 0.052 & 0 \\
$\mathrm{Co}$ & 0.008 & 0.013 & 0.023 & 0 \\
\hline
\end{tabular}

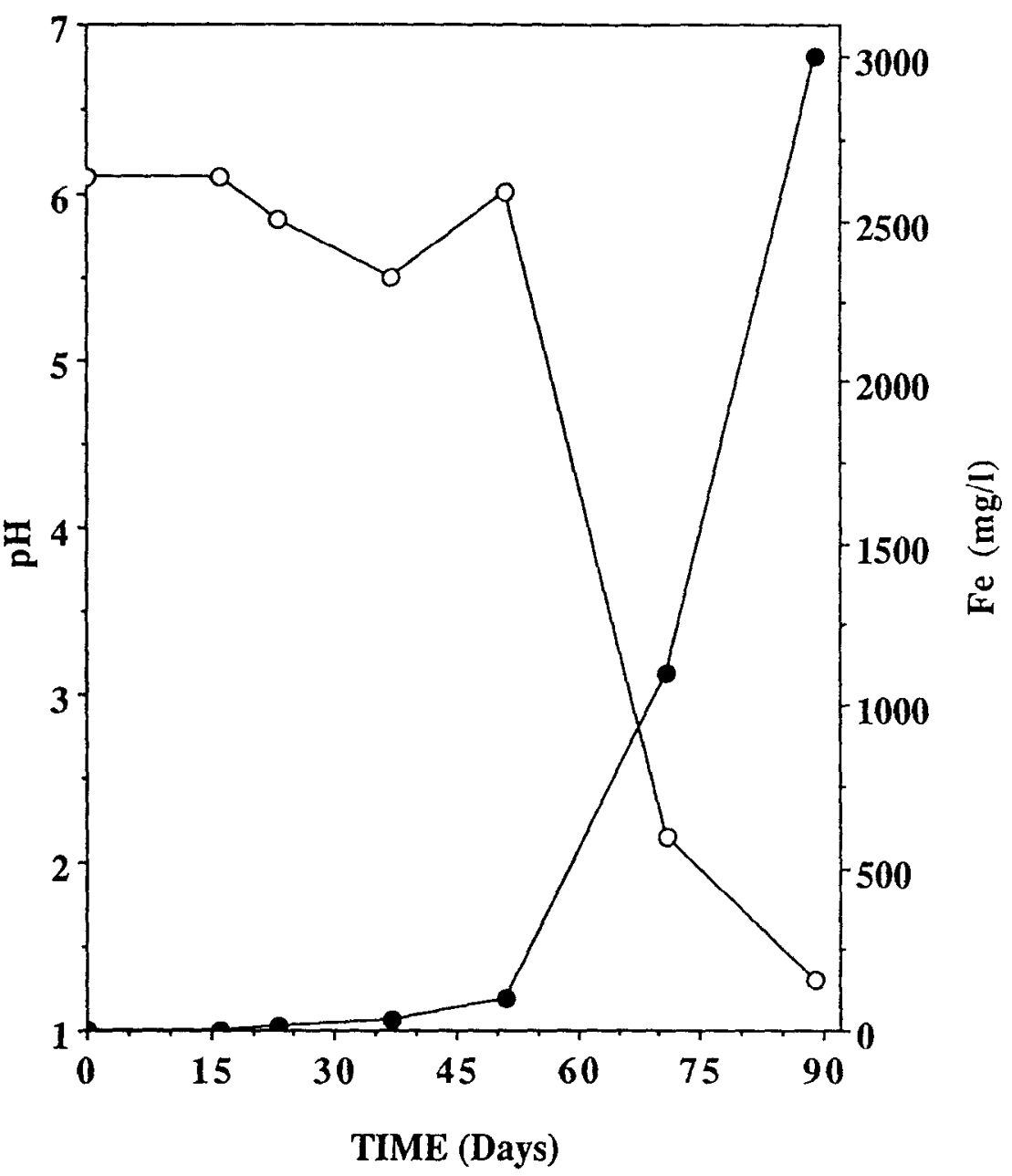

(pulp density $80 \%$ ). The bioleaching process was first followed by determining metal concentrations in solution and by measuring $\mathrm{pH}$ values (Figure 1). Later only the concentration of $\mathrm{Fe}$ released into solution was used as an index of bioleaching activity. The pyrite containing $0.01,0.25$ and $0.50 \%$ of calcite was leached by T. ferrooxidans strain ATCC 13661, but not the samples with 0.75 and $1.01 \%$ of carbonates. For pyrite with a given calcite content, the soluble metals, $\mathrm{Fe}, \mathrm{Zn}$ and $\mathrm{Co}$, were first detected in solution at the same time, but for different calcite contents. The start of the bio-oxidation was directly related to carbonate concentration. The lag phases detected were: 13 days for $0.01 \%$ of calcite content, 38 days for $0.25 \%$ and 190 days for $0.50 \%$. The maximum concentrations of $\mathrm{Fe}$, $\mathrm{Zn}$ and $\mathrm{Co}$ in solution were reached after 80,120 and 315 days, respectively, after inoculation and ranged from 4600 to $7500 \mathrm{mg} \mathrm{Fe} / 1,45$ to $62 \mathrm{mg} \mathrm{Zn/l}$ and 14 to $18 \mathrm{mg} \mathrm{Co} / 1$ (Figures 2-4). In uninoculated samples and in those with 0.75 and $1.01 \%$ of calcite, no metals were detected in solution. In the latter, $\mathrm{pH}$ was still neutral after one year.

For soluble $\mathrm{Fe}$ (Table 2), the bioleaching rate was closer $(5.05$ to $14.7 \mathrm{mg} / \mathrm{l} / \mathrm{h}$ ) to the rates reported in the interlaboratory calibration $(12 \mathrm{mg} / \mathrm{l} / \mathrm{h})$. The bioleaching rate for $\mathrm{Fe}, \mathrm{Co}$ and $\mathrm{Zn}$ (Table 2) increased significantly with the percentage of dissolved calcite. There is probably an increase in $\mathrm{CO}_{2}$ concentrations from calcite dissolution in the interstitial water of the pyrite bulk. This excess $\mathrm{CO}_{2}$ would favour the metabolism of the chemolithotroph $T$. ferrooxidans, which uses this gas as a carbon source (Ingledew 1982).

The concentration ratio of soluble metals was different from the metal content of pyrite ore (Table 3). Zinc is more soluble than $\mathrm{Co}$ and $\mathrm{Fe}$, because it is probably 
Figure 2. Bioleaching of $\mathrm{Fe}$ in air-lift percolators from pyritic ores containing $0.01 \%(\square)$, $0.25 \%(O), 0.50 \%(\triangle)$, and $1.01 \%(\Delta)$ of calcite and showing different lag phase spans directly correlated to calcite content.

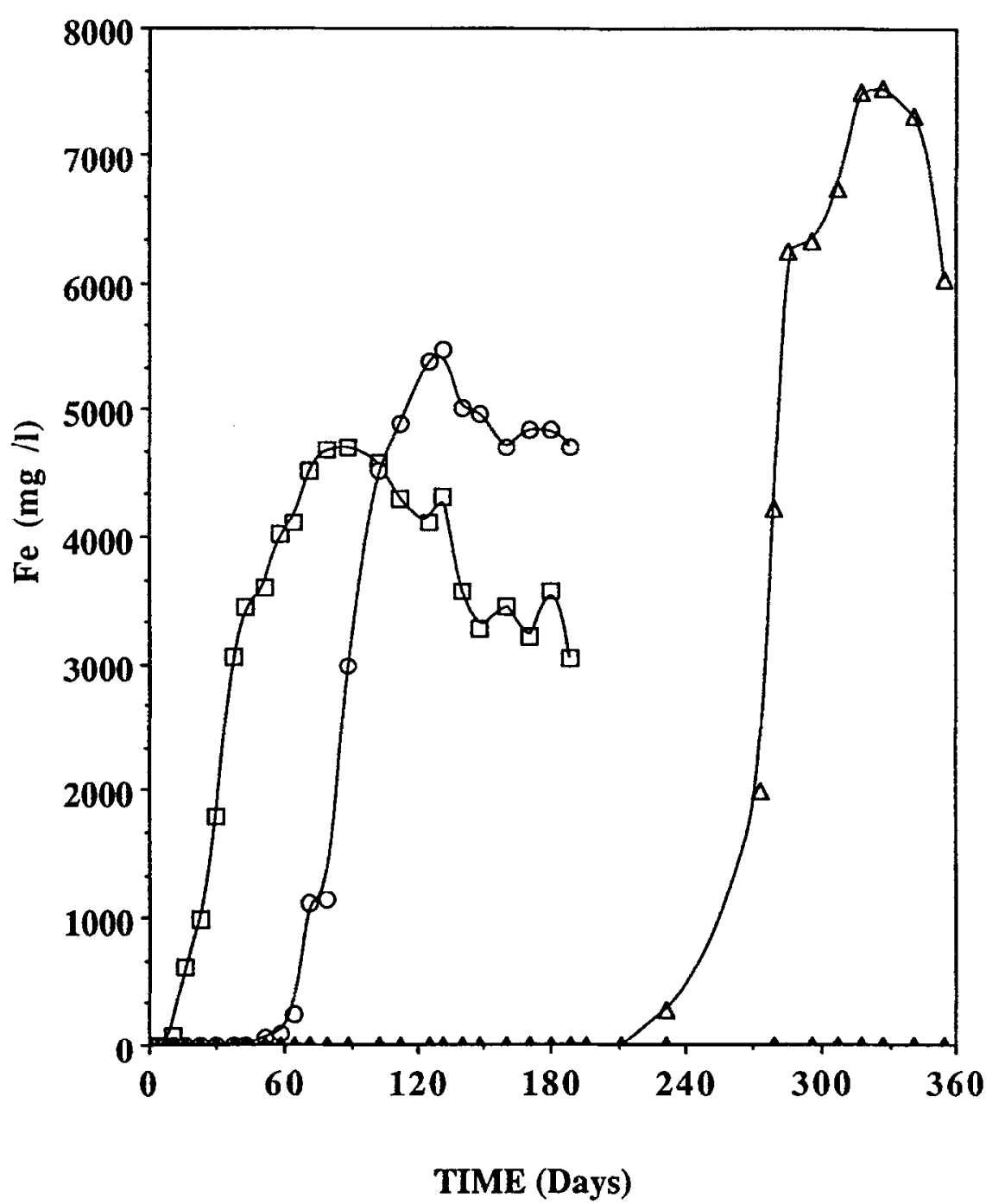

ultraincluded as sphalerite $(\mathrm{ZnS})$, a more soluble sulphide than pyrite (Yakhontova 1985). Cobalt on the other hand, replaces $\mathrm{Fe}$ in the pyrite lattice.

The dissolution pattern of $\mathrm{Ca}$ was completely different from that of other metals (Figure 5). First, the $9 \mathrm{~K}$ medium and then the continuous refilling with acid water $(\mathrm{pH} 2)$ dissolved calcite. In the first weeks, dissolved Ca concentrations did not depend on the calcite content of the pyrite, and reached 350 to $420 \mathrm{mg} / \mathrm{l}$ in all percolator liquors. This range depended on continuous sampling, evaporation and refilling with acid solution. Conversely, the time required to entirely dissolve the calcite by acid additions depended on the content of calcite in the pyritc orc. $T$. ferrooxidans began to grow in the mineral bulk after the calcite had completely disappeared and the optimal growth $\mathrm{pH}$ was attained. However, the $\mathrm{Ca}^{2+}$ in solution remained relatively constant, until the soluble metal concentrations

Table 3. Ratio between metals in pyrite ore and in leaching solution.

\begin{tabular}{lccr}
\hline $\begin{array}{c}\text { Metal } \\
\text { couples }\end{array}$ & $\begin{array}{c}\text { Ratio in } \\
\text { pyrite ore }\end{array}$ & $\begin{array}{c}\text { Ratlo in } \\
\text { leachate }\end{array}$ & $\begin{array}{c}\text { Concentration } \\
\text { factor }\end{array}$ \\
$\mathrm{Co} / \mathrm{Fe}$ & 0.0016 & 0.003 & 1.9 \\
$\mathrm{Zn} / \mathrm{Fe}$ & 0.0011 & 0.011 & 10.0 \\
$\mathrm{Zn} / \mathrm{Fe}$ & 0.70 & 3.5 & 5.0 \\
\hline
\end{tabular}


Figure 3. Bioleaching of $\mathrm{Zn}$ in air-lift percolators from pyritic ores containing $0.01 \%(\square), 0.25 \%(O), 0.50 \%(\triangle)$, and $1.01 \%(\boldsymbol{\Delta})$ of calcite and showing different lag phase spans directly correlated to calcite content.

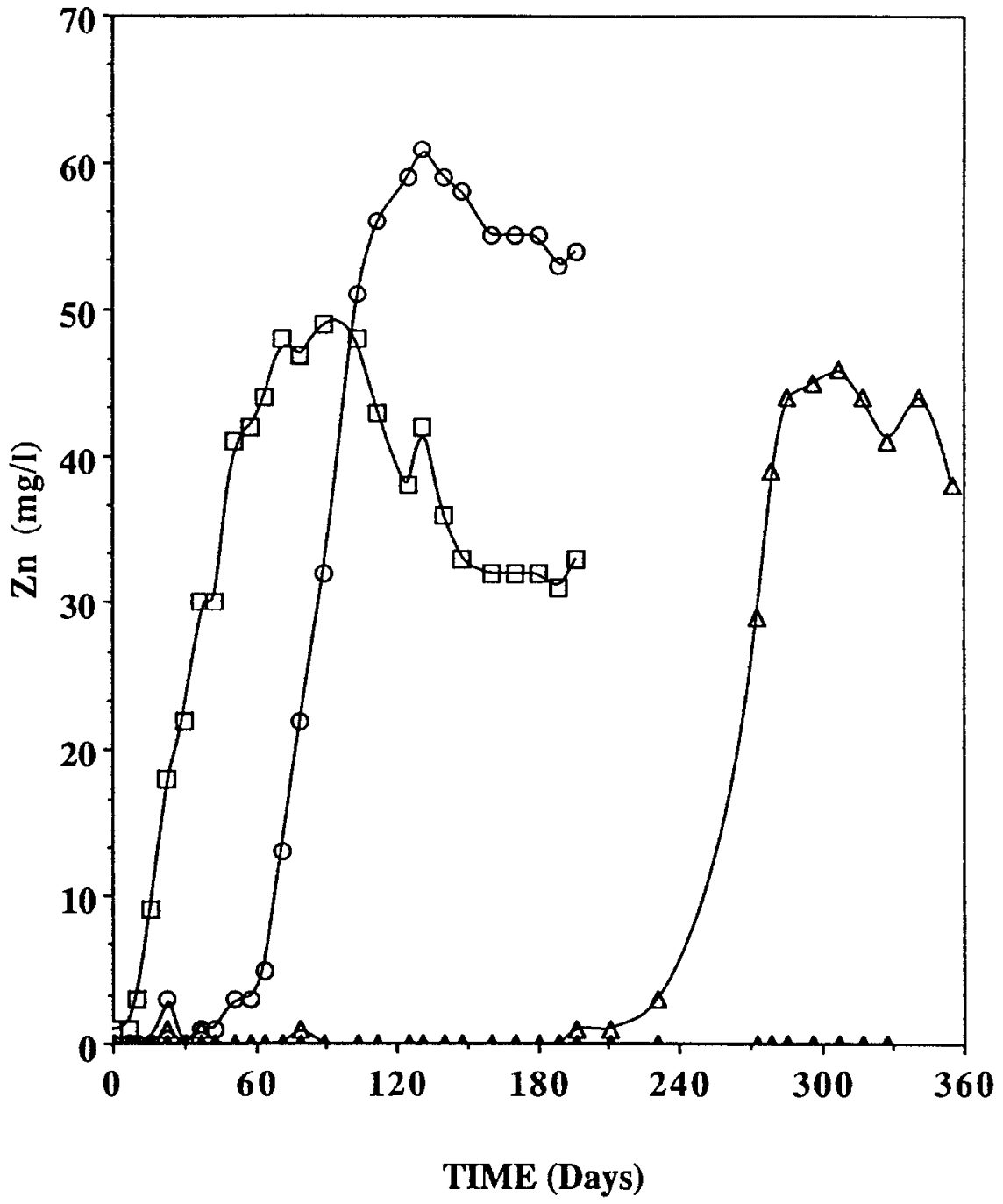

reached a maximum, after which $\mathrm{Ca}^{2+}$ concentrations decreased (Figure 5) due to the depletion of $\mathrm{CaCO}_{3}$ source, and continuous sampling which lasted several months.

Determination of total metals in the colloid phase $(1.08 \mathrm{mg} / \mathrm{ml})$, in the presence of carbonate-free pyrite, showed high concentrations of Fe (157 mg/g dry wt), $\mathrm{Zn}(1.25 \mathrm{mg} / \mathrm{g})$ and $\mathrm{Co}(0.37 \mathrm{mg} / \mathrm{g})$. Thus, $5.6 \%$ of $\mathrm{Fe}$ was in colloidal form and the remaining $94.4 \%$ was soluble; $4.2 \%$ of $\mathrm{Zn}$ and $4.4 \%$ of Co occurred as colloids. Colloidal co-precipitation of metals may take place, resulting in the trapping of small particles in the ore bulk, but accounts only for about $5 \%$ of the decline in metal concentrations in the later stage of the leaching bioprocess (Figures 2 to 4), with respect to a major metal loss due to the continuous liquor sampling. This decline was mostly accounted for by liquor sampling and was obscrved to depend on the number of samples taken.

\section{Flask Experiments}

This experiment was performed to confirm the effect of calcite on pyrite bioleaching. Only $\mathrm{Fe}, \mathrm{Ca}$ and titratable acidity were determined in the liquor as indexes for bioleaching and calcite dissolution.

Calcium dissolution data is not reported because it followed the same pattern as in percolators. In the flask experiments, the lag phase spans were significantly different from those in the percolator study and were characterized by $\mathrm{Fe}$ 
Figure 4. Bioleaching of Co in air-lift percolators from pyritic ores containing $0.01 \%(\square), 0.25 \%(O), 0.50 \%(\triangle)$ and $1.01 \%(\Delta)$ of calcite and showing different lag phase spans directly correlated to calcite content.

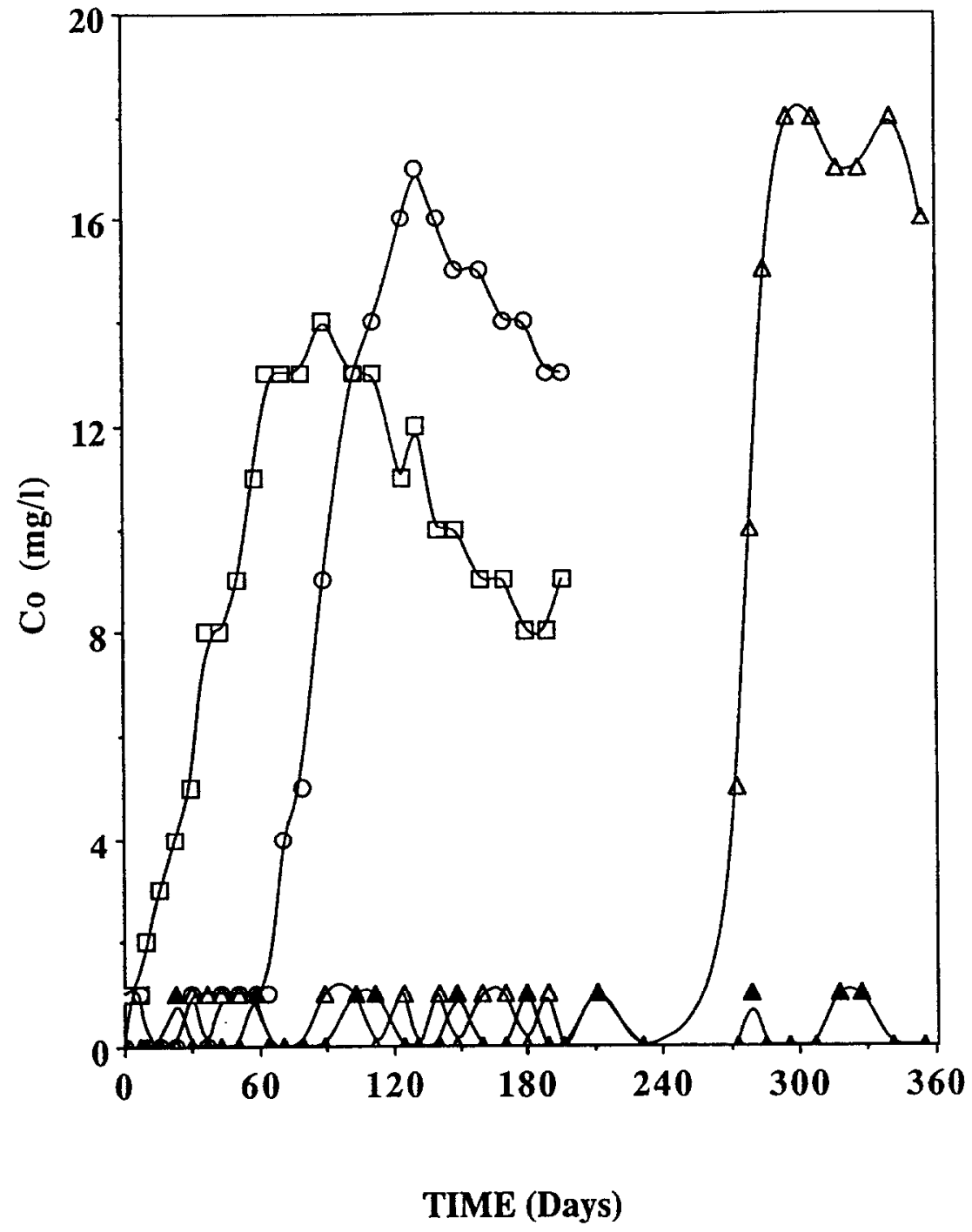

concentrations in the liquor. In fact, the bioleaching of pyrite occurred more rapidly. The lag phases determined from Fe solubilization curves (Figure 6), were 2 days for $0.01 \%$ calcite content, 15 days for 0.05 to $0.10 \%, 20$ days for 0.20 to $0.30 \%, 32$ days for $0.40 \%$, and 65 days for $0.60 \%$. The original pyrite $(1.01 \%$ calcite) was not oxidized by T. ferrooxidans strain ATCC 13661 after 90 days of incubation. The $\mathrm{Fe}$ concentrations were inversely correlated to calcite content in pyrite. The maximum concentration of $\mathrm{Fe}(1700 \mathrm{mg} / \mathrm{l})$ in solution occurred in the sample without calcite, whereas in the pyrite with more calcite, $\mathrm{Fe}$ concentration dropped to $250 \mathrm{mg} / \mathrm{l}$, as, for example, with $0.60 \%$ of calcite (Figure 5).

The Fe bioleaching rates were lower than in the percolator study, ranging from $2 \mathrm{mg} / \mathrm{l} / \mathrm{h}$ in the sample with carbonate-free pyrite down to $0.36 \mathrm{mg} / \mathrm{l} / \mathrm{h}$ in the sample with $0.60 \%$ of carbonate (Figure 6 ). The acid production rate from pyrite bio-oxidation also diminished in the bioleaching liquor depending on the calcite content of the pyrite ores (Figure 7).

\section{Discussion}

Thiobacillus ferrooxidans strain ATCC 13661 can oxidize pyrites provided they contain only traces of calcite. However, this acidophilic micro-organism can survive at neutral $\mathrm{pH}$ for a long time, and as soon as conditions are favourable, 
Figure 5. Concentrations of $\mathrm{Ca}$ in the bioleaching liquor of air-lift percolators with different pyrite ores containing $0.01 \%(\square)$, $0.25 \%(O), 0.50 \%(\triangle)$ and $1.01 \%(\Delta)$ of calcite.

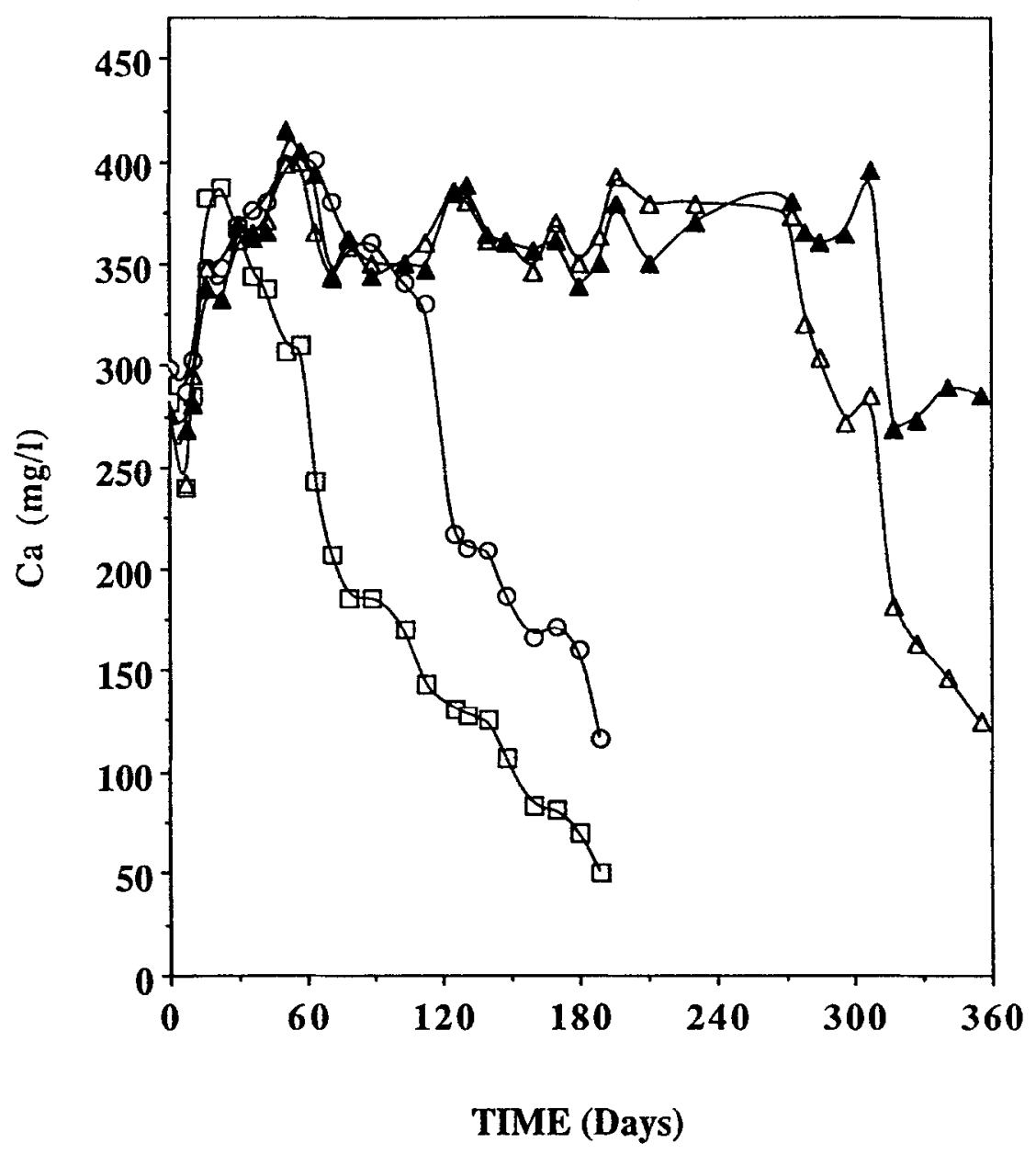

it starts oxidizing the mineral bulk. The survival of the organism at neutral $\mathrm{pH}$ is not surprising because of its isolation from high $\mathrm{pH}$ natural environments. Olson et al. $(1979,1981)$ regularly found an abundance of acidophilic iron- and sulphur-oxidizing autotrophs around alkaline pyrite-containing coal mines in southern Montana (USA), despite the high $\mathrm{pH}$ of drainage waters. In addition, strains of $T$. ferrooxidans have been isolated by us from calcareous sulphide deposits in Sardinia (Italy). T. ferrooxidans probably survives in a state of dormancy or is localized in acidic microzones (Van Voast \& Hedges 1975).

The results of the two studies were contradictory for the following reasons: (1) in the percolator system, the bioleaching rates of $\mathrm{Fe}$ were higher and increased with the amount of dissolved calcite, the same was true of $\mathrm{Zn}$ and $\mathrm{Co}$; (2) in the flask experiments, the $\mathrm{Fe}$ bioleaching rate was about half that in the percolator system for minimum calcite content (up to $0.15 \%$ ), and about 30 times less when the calcite content was above $0.25 \%$; (3) on the other hand, the lag phase spans for $T$. ferrooxidans in the flask study wcre significantly shorter. These differences in metal extraction between the percolator and flask experiments can be explained by the different characteristics of the two systems and depend on if the acid solution is added, on different sites of gypsum precipitation (outside or in the mineral bulk), and on the final $\mathrm{pH}$ of the bioleaching solution.

In the percolators, a few $\mathrm{ml}$ of acidified water per week were added to maintain the constant volume of the leaching liquor, and the larger lag time is linked to the more gradual dissolution of calcite, which keeps the micro-organism in a dormant state. 
Figure 6. Dissolution of $\mathrm{Fe}$ in Erlenmeyer flasks from different samples of pyrite ore containing variable concentrations of calcite: $0.01 \%(\square), 0.05 \%(O), 0.10 \%(\triangle)$, $0.20 \%(\mathbb{G}), 0.30 \%(\mathbf{O}), 0.40 \%(\Delta), 0.60 \%$ (一 $\square$ ), and $1.01 \%(-\mathrm{O}-)$.

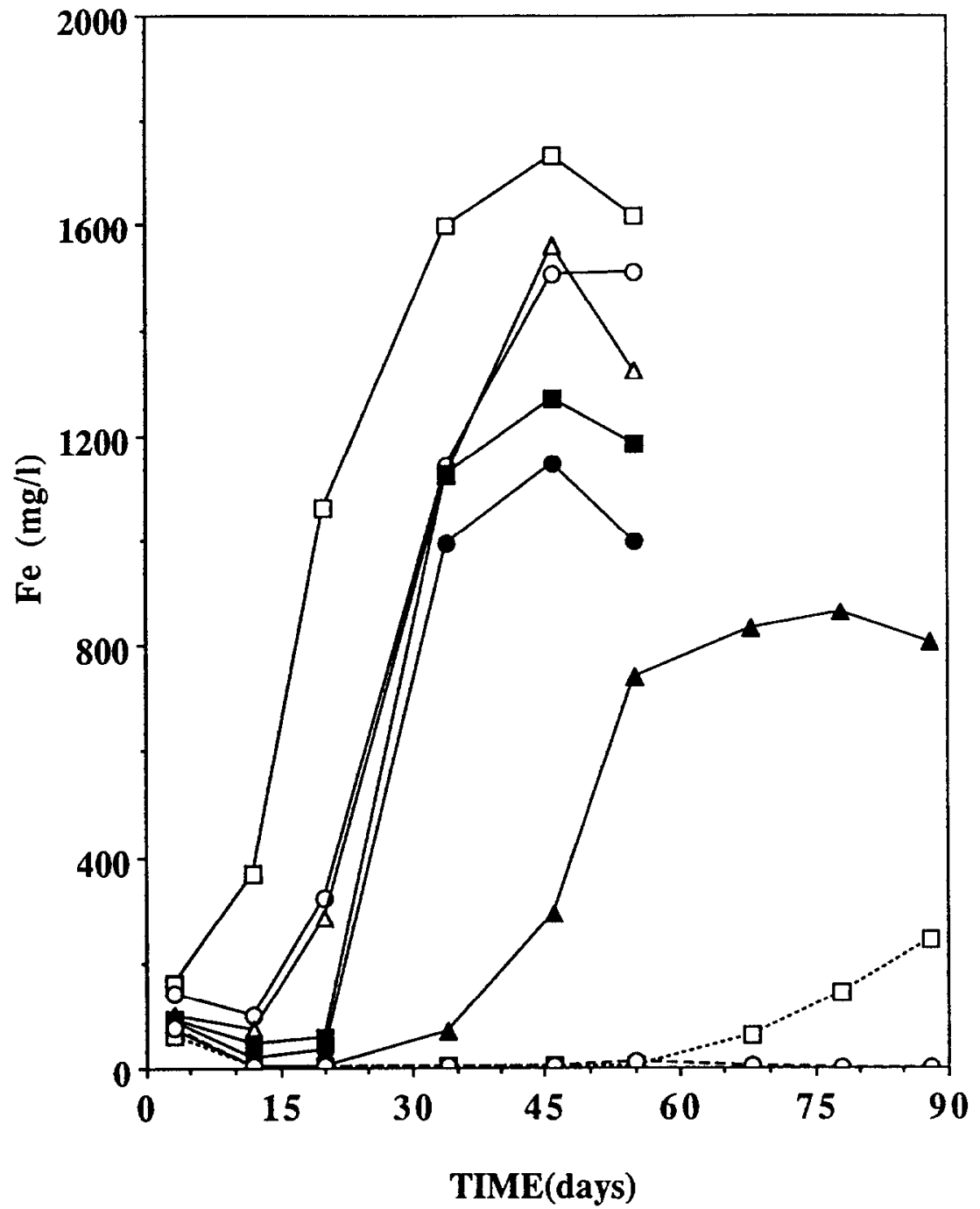

In the flask study, the larger amount of acidified medium added at the beginning dissolved more calcite $(0.40 \%)$ and the lag phase spans were consequently shorter.

The bioleaching rates of metals tended to be higher in percolators with pyrite ore containing more dissolved calcite, probably because the $\mathrm{CO}_{2}$ generated by dissolving carbonates in the interstitial water of the pyrite bulk is utilized by the chemolithotroph $T$. ferrooxidans as a carbon source. In addition calcite is transformed to gypsum which precipitated on the percolator wall at the water-air interface, outside the mineral bulk. The optimal $\mathrm{pH}$ to bio-oxidize the mineral ore is also reached in the liquor.

In the flasks, on the other hand, the bioleaching rates decreased with calcite content because the newly formed gypsum precipitated in the mineral bulk. The pyrite assumed a milky-brown colour and the bio-availablc surfacc of the mincral was diminished. The acidity in the liquor is not optimal, especially in those with high calcite content, and consequently affects the Fe concentrations, which tend to precipitate from the liquor as jarosite.

Regarding the biological extraction of $\mathrm{Co}$ and $\mathrm{Zn}, \mathrm{Zn}$ was more readily extracted than Co.

The removal of carbonates could provide a solution in cases in which pyrite contains high concentrations of more soluble strategic metals. Chemical or biological pretreatment to remove the carbonic gangue could be considered in cases of promising good metal recovery from sulphide ores. 
Figure 7. Bioleaching rates of $\mathrm{Fe}(\square)$ and acid production $(\triangle)$ calculated by $\mathrm{ml} \mathrm{NaOH}$ $1.0 \mathrm{M}$ added to the sample, in Erlenmayer flasks for different calcite concentrations in the pyrite ores.

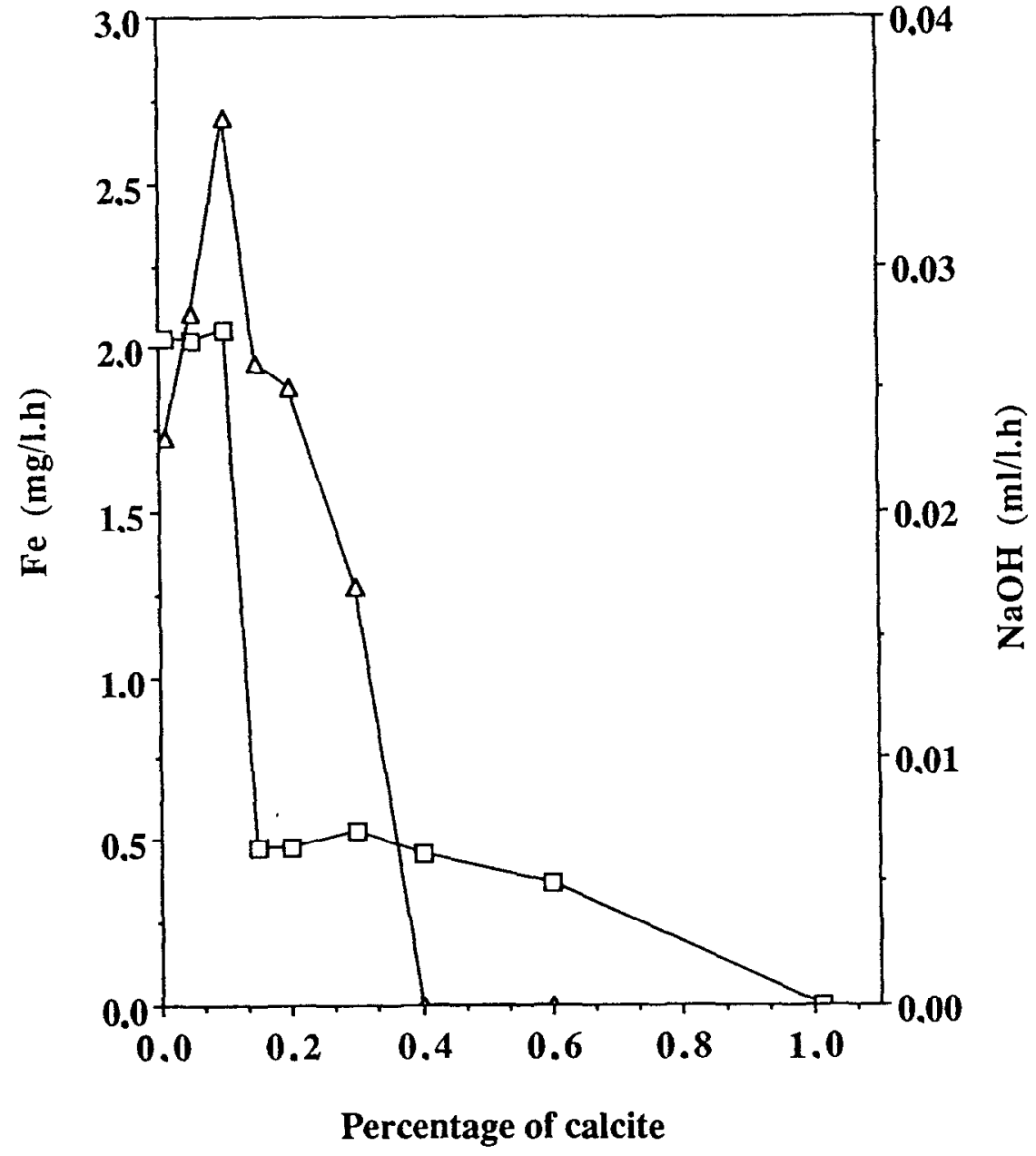

In addition, $\mathrm{Ca}^{2+}$ concentrations in the bioleaching solution are a good indicator of the efficiency of the bioprocess and are more useful than carbonate concentrations in ores, because calcite can occur as lumps in sulphide deposits.

\section{References}

BALDI, F. \& OLSON, G.J. 1987 Effects of cinnabar on pyrite oxidation by Thiobacillus ferrooxidans and cinnabar mobilization by a mercury resistant strain. Applied Environmental Microbiology 53, 772-774.

BARBIC, F.F. 1977 Effects of different compounds of metals and of their mixtures on the growth and survival of Tbiobacillus ferrooxidans. Zeitscbrift für allgemeine Mikrobiologie 17, 277-281.

Boseker, K., Neuschutz, D. \& SCHEFFLer, U. 1978 Microbiological leaching of carbonate-rich German copper-shale. In Metallurgical Applications of Bacterial Leaching and Related Microbiological Phenomena, eds Murr, L.E., Torma, A.E., \& Brierley, J.A., pp. 389-401, New Yurk: Academic Press.

BRIERLEY, C.L. 1978 Bacterial leaching. Critical Review of Microbiology 6, 207-262.

Dugan, P. P., MacMillan, C.B. \& Pfister, R.M. 1970 Aerobic heterotrophic bacteria indigenous to $\mathrm{pH} 2.8$ acid mine water: predominant slime producing bacteria in acid streamers. Journal of Bacteriology 101, 982-988.

EHRLICH, H.L. 1987 Bioleaching of silver from mixed sulphide ore in a stirred reactor. In Biobydrometallurgy: Proceedings of an International Symposium, University of Warwick, 1987, eds Norris, P.R. \& Kelly, D.P., pp. 223-231. Chippenham, Wiltshire, UK: Antony Rowe Ltd.

Groudev, S.N., GENCHEv, F.N. \& GAIDARJIEV, S.S. 1978 Observation of the microflora in an industrial copper dump leaching operation. In Metallurgial Application of Bacterial Leacbing and Related Microbiological Pbenomena, eds Murr, L.E., Torma, A.E. \& Brierley, J.A. pp. 253-274. New York: Academic Press. 
Imai, K. Sugio, T., Tsuchida, T. \& TANO, T. 1975 Effects of heavy metal ions on the growth and iron-oxidizing activity of Tbiobacillus ferrooxidans. Agricultural and Biological Chemistry 39, 1349-1354.

INGLEDEW, J.W. 1982 Tbiobacillus ferrooxidans. The bioenergetics of an acidophilic chemolithotroph. Biochimica et Biopbysica Acta 683, 89-117.

Ishikawa, T., Murayama, T., Kawahara, I. \& Imaizumi, T. 1983 Treatment of acid mine drainage utilizing bacterial oxidation. In Recent Progress in Biobydrometallurgy, eds Rossi, G. \& Torma, A.E. pp. 393-407. Iglesias, Italy: Associazione Mineraria Sarda.

KELly, D.P. \& HARRISON, A.P. 1989 Genus Tbiobacillus. In Bergey's Manual of Systematic Bacteriology, Vol. 3. cd. Stalcy, J.T., pp. 1842 1858. Baltimorc, MD: Williams and Wilkins.

Kelly, D.P., Norris, P.R. \& Brierley, C.L. 1979 Microbiological methods for the extraction and recovery of metals. In Microbial Technology: current state, future prospects, Vol. 29, Symposium of the Society for General Microbiology, eds Bull, A.T., Ellwood, D.C. \& Ratlcdge, C. pp. 263 308. Cambridge: Cambridge University Press.

KHALID, Z.M., MAHMMOD, T. \& MALIK, K.A. 1987 Leaching of a carbonate bearing uranium ore with a selected strain of Thiobacillus thiooxidans. In Biohydrometallurgy: Proceedings of an International Symposium, University of Warwick, 1987, eds Norris, P.R. \& Kelly, D.P. p. 524. Chippenham, Wiltshire, UK: Antony Rowe Ltd.

MAILPATR , R.S.S. \& MisirR , A.K. 1984 Inhibition in Thiobacillus ferrooxidans by toxic metals and its alleviation by EDTA. Current Microbiology 11, 1-6.

Olson, G.J., MCFeters, G.A. \& Temple, K.L. 1981 Occurrence and activity of iron- and sulfur-oxidizing microorganisms in alkaline coal strip mine spoils. Microbial Ecology 7, 39-50.

Ot.SON, G.J., Turbak, S.C. \& MCFETERS, G.A. 1979 Impact of Western coal mining-II. Microbiological studies. Water Research 13, 1033-1041.

Paknikar, K.M. \& Agate, A.D. 1987 Occurrence of a Tbiobacillus ferrooxidans strain tolerating unusually high concentrations of metals and an associated metal-tolerant acidophilic heterotrophic bacterium. In Biobydrometallurgy: Proceedings of an International Sympasizm, University of Warwick, 1987, eds Norris, P.R. \& Kelly, D.P., pp. 223231. Chippenham, Wiltshire, UK: Antony Rowe Ltd.

Pinches, A., Chapman, J.'T., Te Riele, W.A.M. \& Van Staden, M. 1987 The performance of bacterial leach reactors for the preoxidation of refractory gold-bearing sulphide concentrates. In Biobydrometallurgy: Proceedings of an International Symposium, University of Warwick, 1987, eds Norris, P.R., \& Kelly, D.P., pp. 329-344. Chippenham, Wiltshire, UK: Antony Rowe Ltd.

SCHAFER, W. 1983 Leaching of industrial wastes products with thiobacilli and heterotrophic microorganisms. In Recent Progress in Biobydrometallurgy, eds Rossi, G. \& Torma, A.E. pp. 427-440. Iglesias, Italy: Associazione Mineraria Sarda.

Silverman, M.P. \& LUNDGREN, D.G. 1959 Studies on the chemoautotrophic iron bacterium Ferrobacillus ferrooxidans-I. An improved medium and harvesting procedure for securing high cell yields. Journal of Bacteriology 77, 642-647.

SkOOG, D.A. \& WEST, D.M. 1979 Analytical Chemistry. New York: Holt, Rinehart and Winston.

SugIO, T., TANO, T. \& IMAI, K. 1981 Isolation and some properties of silver ion-resistant iron-oxidizing bacterium Thiobacillus ferrooxidans. Agricultural Biological Chemistry 45, 2037-2051

TuOvinen, O.H. \& KELLY, D.P. 1974 Studies on the growth of Thiobacillus ferrooxidans-II. Toxicity of uranium to growing cultures and tolerance conferred by mutation, other metal cations and EDTA. A rchiv für Mikrobiologie 95, 153-164.

VAN VOAST, W.A. \& Hedges, R.B. 1975 Hydrogeological aspects of existing and proposed strip coal mines near Decker, southeastern Montana. Bulletin No. 97. State of Montana, Bureau of Mines and Geology, Butte, MT.

Wallace, W.A., Mueller, R.T., Datel, P.M. \& Soufi, S.M. 1976 Use of waste pyrites from mine operations on highly calcareous soil. Communication in Soil Science and Plant Analysis 7, 57-60.

WICHLACZ, P.L. \& ThOMPSON, D.L. 1987 The effects of acidophilic heterotrophic bacteria on the leaching of cobalt by Thiobacillus ferrooxidans. In Biobydrometallurgy: Proceedings of an International Symposium, University of Warwick, 1987, eds Norris, P.R. \& Kelly, D.P., pp. 77-86. Chippenham, Wiltshire, UK: Antony Rowe Ltd.

YAKHONTOVA, L.K. 1985 The role of the sulphide constitution in the process of their bacterial leaching, ed. Karavaiko, G.I. \& Groudev, S.N. pp. 216-226. Moscow: Centre International Project GKNT.

(Received 10 August 1990; revised 17 October 1990; accepted 14 November 1990) 